\title{
THE COMBINATION OF SILK AND WOOL WITH POSITIVE AND NEGATIVE IONS
}

\author{
By Milton Harris ${ }^{1}$
}

\section{ABSTRACT}

Wool, with an isoelectric point at $\mathrm{pH} 3.4$, combines with negative ferrocyanide ion in solutions ranging in $\mathrm{pH}$ up to about 5.0 and with positive nickel ion in solutions ranging in $\mathrm{pH}$ down to about 2.0. Similarly silk, with an isoelectric point of $\mathrm{pH} 2.5$, combines with ferrocyanide ion up to about $\mathrm{pH} 4.0$ and with nickel ion down to about $\mathrm{pH}$ 1.8. Evidently these amphoteric proteins combine with both positive and negative ions over a certain range on both sides of the isoelectric point. The extent of this "isoelectric region" depends upon the ions employed as well as upon the protein. The limiting values obtained for the $\mathrm{pH}$ at which ions combine with a protein do not necessarily represent the isoelectric point of the protein.

CONTENTS

Page

I. Introduction .

II. Theoretical

III. Review of previous work

IV. Experimental $\ldots \ldots \ldots 78$

V. Conclusions

VI. Acknowledgment.... 478

\section{INTRODUCTION}

Quantitative determinations of the combination of proteins with ions are made by electrometric methods. Qualitative determinations are made by employing salts containing colored ions or ions which may form colored compounds on treatment with the proper reagents. Both methods have been used for the determination of the isoelectric point. It is the purpose of this paper to show the possibilities and limitations of such methods.

\section{THEORETICAL}

A colloidal (or other) particle is at its isoelectric point when the particle is electrically neutral with respect to its surrounding medium. For an amphoteric substance at its isoelectric point, the concentration of the anions is equal to that of the cations. That the sum of the anion and cation concentration is a minimum may be proved as follows:2,3 Consider an amphoteric electrolyte of the type HROH. The law of mass action gives the following relationship:

$$
\begin{aligned}
& \frac{\left[\mathrm{HR}^{+}\right]\left[\mathrm{OH}^{-}\right]}{[\mathrm{HROH}]}=K_{b} \\
& \frac{\left[\mathrm{ROH}^{-}\right]\left[\mathrm{H}^{+}\right]}{[\mathrm{HROH}]}=K_{a}
\end{aligned}
$$

At the isoelectric point $\left[\mathrm{HR}^{+}\right]=\left[\mathrm{ROH}^{-}\right]$; therefore

$$
K_{b} \frac{[\mathrm{HROH}]}{\left[\mathrm{OH}^{-}\right]}=K_{a} \frac{[\mathrm{HROH}]}{\left[\mathrm{H}^{+}\right]}
$$

1 Research associate representing the American Association of Textile Chemists and Colorists.

2 W. M. Clark, The Determination of Hydrogen Ions, p. 32, Williams \& Wilkins Co., 1928.

' L. Michaelis, Hydrogen Ion Concentration, pp. 62-65, Williams \& Wilkins Co., 1926. 
Since $\mathrm{K}_{w}=\left[\mathrm{H}^{+}\right]\left[\mathrm{OH}^{-}\right]$then (3) reduces to

$$
\left[\mathrm{H}^{+}\right]=\sqrt{\frac{K_{a}}{K_{b}} \times K_{\text {to }}}
$$

From equations (1) and (2) we may write

$$
\left[\mathrm{HR}^{+}\right]=\left[\mathrm{ROH}^{-}\right]=K_{b} \frac{[\mathrm{HROH}]\left[\mathrm{H}^{+}\right]}{K_{w}}+K_{a} \frac{[\mathrm{HROH}]}{[\mathrm{H}]^{+}}
$$

Let $X=\left[\mathrm{HR}^{+}\right]+\left[\mathrm{ROH}^{-}\right] \quad$ For $X$ to be a minimum, $\frac{d X}{d\left[\mathrm{H}^{+}\right]}$must equal 0. This condition is fulfilled when $\left[\mathrm{H}^{+}\right]=\sqrt{\frac{K_{a}}{K_{b}} \times K_{w}}$ which is the value of $\left[\mathrm{H}^{+}\right]$at the isoelectric point given in equation (4). Therefore $X$, the sum of the anion and cation concentrations, is a minimum at the isoelectric point.

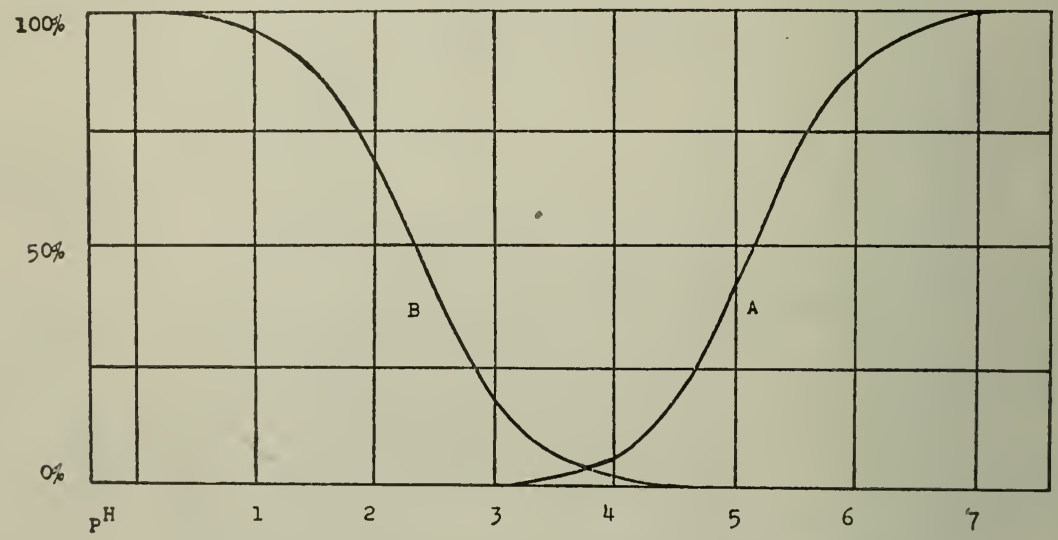

Figure 1.-Dissociation curves of p-amino-benzoic acid

That the ionization at this point is not zero is clearly shown in the dissociation curves of $p$-amino benzoic acid. ${ }^{4}$ (Fig. 1.) They intersect at $\mathrm{pH} 3.77$ which is the isoelectric point of this ampholyte. It is apparent from the curves that $p$-amino benzoic acid combines with

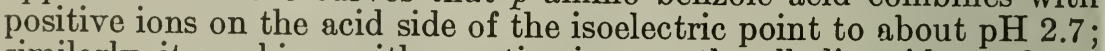
similarly, it combines with negative ions on the alkaline side to about $\mathrm{pH}$ 4.9. These two points are the approximate limits of what may be called its isoelectric range.

If curves $A$ and $B$ intersected at zero per cent dissociation, the point of intersection would represent the isoelectric point. Moreover, if the two curves are symmetrical the isoelectric point will be the mean of the two limits. Such measurements might therefore be useful for defining approximately the isoelectric point. The suitability of such methods will depend largely on the sensitivity with which the limits of combination of the ions can be determined. The principle is illustrated by the data given on page 477 which show that the mean of the two limits for wool is 3.5 while the isoelectric point determined by migration is 3.4. The agreement for silk, for which the values are 2.9 and 2.5, respectively, is not so good, probably because of the difficulty noted in detecting the limits of combination. 


\section{REVIEW OF PREVIOUS WORK}

Northrop and Kunitz ${ }^{5}$ have contributed considerable data on the combination of gelatin with cations and anions on both sides of the isoelectric point. They used concentration cells and a method based on the measurement of membrane potentials for those ions for which no electrode was available. They found that gelatin combines appreciably with copper in acid solutions to $\mathrm{pH} 2$ and with calcium to $\mathrm{pH} 2.5$, values which are considerably on the acid side of the isoelectric point of $\mathrm{pH} 4.7$.

Pauli and Schön ${ }^{6}$ measured the combination of undenatured egg albumin with zinc chloride. Chloride ion was found to be in a bound condition up to about $\mathrm{pH}$ 6. This justified Pauli's contention that negatively charged protein was capable of combining with the anion of the salt.

Carroll and Hubbard ${ }^{7}$ found that the amount of silver ion combined with gelatin increases with increasing $\mathrm{pH}$, but does not fall to zero on the acid side of the isoelectric point.

Loeb, ${ }^{8}$ Speakman, ${ }^{9}$ and Denham and Brash ${ }^{10}$ have reported values for the isoelectric points of gelatin, wool, and silk, respectively, obtained qualitatively from the reactions of salts with these substances. The value which Loeb obtained for the isoelectric point of gelatin is in good agreement with values obtained by other workers employing various methods. The values which Speakman and Denham and Brash obtained for the isoelectric points of wool and silk are not in good agreement with those obtained by other workers. ${ }^{11}$

Speakman treated samples of wool with standard potassium ferrocyanide solutions of known $\mathrm{pH}$. After 24 hours the wool was removed and carefully washed to remove uncombined ferrocyanide and then immersed in ferric chloride solution to form the blue ferriferrocyanide. By this procedure he found that when the $\mathrm{pH}$ was high no combination with the ferrocyanide ion occurred; at pH 4.8 combination began and as the $\mathrm{pH}$ decreased the amount of ferrocyanide ion absorbed by the wool increased. He concluded from this that the isoelectric point of wool was in the neighborhood of $\mathrm{pH} 4.8$. In his paper only the combination with negative ferrocyanide ion was reported, no experiments with positive ions being mentioned.

Denham and Brash treated samples of silk with copper acetate, silver nitrate, and potassium chromate. Using copper acetate, they estimated the isoelectric point of China silk to be at $\mathrm{pH} 3.9$, but with tussah silk they found it to be between $\mathrm{pH} 3.0$ and 3.7. U'sing silver nitrate they found the results to be "less definite but indicated that the

s J. H. Northrop and M. Kunitz, Combination of Salts and Proteins, J. Gen. Physiol., vol. 7, p. 25, 1924 ; vol. 9, p. 351, 1926; vol. 11, p. 481, 1928.

${ }_{6}$ W. Pauli and Schön, Untersuchungen an Elektrolytfreien, Wasserloslichen Proteinen, Biochem. Zeit., vol. 153 , pp. $253-284,1924$.

7 B. H. Carroll and D. Hubbard, The Photographic Emulsion-The Silver Ion-Gelatin Equilibrium, B. S. Jour. Research vol. 7, pp. 811-825, 1931.

Jacques Loeb, Proteins and the Theory of Colloidal Behavior, p. 28, McGraw-Hill Co.

- J. B. Speakman, The Behavior of Wool as an Amphoteric Colloid, J. Soc. Dyers and Colourists, vol. 41, pp. $172-179,1925$.

${ }_{10}$ W. Denham and W. Brash, The Isoelectric Point of Silk Fibroin, J. Text. Inst., vol. 18, pp. T520-525, 1927.

11 L. Meunier and G. Rey, Sur les Propriétés de la Laine, J. Intern. Soc. Leather Trades' Chemists, vol. 11 , p. 508, 1927.

H. R. Marston, The Chemical Composition of Wool, Australia, Council Sci. and Ind. Res. Bull., No. 38, $36 \mathrm{pp} ., 1928$.

M. Harris, The Isoelectric Point of Wool, B. S. Jour. Research, vol. 8, pp. 779-786, 1932.

T. G. Hawley and T. B. Johnson, The Isoelectric Point of Silk, Ind. \& Eng. Chem., vol 22, pp. 297-299, 1930.

M. Harris and T. B. Johnson, Study of the Fibroin from Silk in the Isoelectric Region, Ind. \& Eng. Chem., vol. 22, p. 539, 1930.

L. Meunier and G. Rey, Determination du Point Isoelectrique de la Laine et de la Soie, Compt. Rend., vol. 184, p. 285, 1927.

M. Harris, The Isoelectric Point of Silk, B. S. Jour. Research, vol. 9, pp. 557-560, 1932. 
isoelectric point of fibroin lies at $\mathrm{pH} 4$ or at a less $\mathrm{pH}$ value." In experiments with potassium chromate they found that the chromate ion was not held by the silk at pH 3.7 and above. They concluded that "the determination of the exact position of the isoelectric point in the ways described is therefore not quite certain apart from the question of an isoelectric range or of more than one isoelectric point," but concluded that that point lies between $\mathrm{pH} 3.6$ and $\mathrm{pH} 4.0$.

\section{EXPERIMENTAL}

Samples of wool and boiled-off silk were purified by successive extractions with alcohol and ether until no appreciable residue was obtained on evaporation of the solvent.

The wool samples were treated with a 1 per cent potassium ferrocyanide solution in a $\mathrm{pH}$ range from 2 to 7 . After 24 hours the wool was removed and each sample washed in a buffer solution of the same $\mathrm{pH}$ as the ferrocyanide solution in which it had been soaked. The washing was continued until no ferrocyanide could be detected in the sample treated at $\mathrm{pH} 7$. It was assumed that all ferrocyanide mechanically held by the wool would wash out at the same rate regardless of the $\mathrm{pH}$ and only that chemically combined would be retained. The samples were immersed in a 1 per cent ferric chloride solution for one hour after which they were rinsed and dried. The samples treated above $\mathrm{pH} 5$ showed no color; a light blue appeared at $\mathrm{pH} 5$ and increased in depth as the $\mathrm{pH}$ decreased.

A second set of wool samples were treated with a 5 per cent solution of $\mathrm{NiCl}_{2}$ in a pH range of 1.2 to 7 . After 24 hours the samples were washed with corresponding buffer solutions until no nickel was detectable in the sample at $\mathrm{pH} 1.2$. The wool was then treated with an alcoholic solution of dimethyl glyoxime. Below $\mathrm{pH} 2$ the wool was colorless. At pH 2 a light pink color appeared and increased in samples treated with solutions of increasing $\mathrm{pH}$.

Similar experiments were carried out with silk. Since the acid and basic binding power of silk is very weak, no sharp changes were detectable. The experiments indicated roughly, however, that silk combines with ferrocyanide up to about $\mathrm{pH} 4$ and with nickel down to about $\mathrm{pH} 1.8$.

\section{CONCLUSIONS}

The results of these experiments are in accord with those obtained by Northrop and Kunitz, Carrol and Hubbard, and Pauli and Schön. Taking the values for the isoelectric points of silk and wool to be at $\mathrm{pH} 2.5$ and $\mathrm{pH} 3.4$, respectively, they show that combination with positive or negative ions may take place within a certain range on both sides of the isoelectric points of these proteins. Consequently, values of the isoelectric points obtained by determining the $\mathrm{pH}$ limits of the combinations of positive and negative ions with silk and wool do not necessarily represent the isoelectric points of these substances, but indicate the point above or below which the fiber combines with a given ion. The mean of these limits may give an approximate value for the isoelectric point.

\section{ACKNOWLEDGMENT}

This investigation was made possible by a grant to the American Association of Textile Chemists and Colorists by the Textile Foundation. We wish to express our appreciation for the aid given.

Washington, February 13, 1933. 